\title{
Relationships between tuna catch and variable frequency oceanographic conditions
}

\author{
Franklin Isaac Ormaza-González ${ }^{1}$, Alejandra Mora-Cervetto ${ }^{2}$, and Raquel María Bermúdez-Martínez ${ }^{2}$ \\ ${ }^{1}$ Escuela Superior Politécnica del Litoral (ESPOL), Km 30.5 Vía Perimetral, Guayaquil, Ecuador \\ ${ }^{2}$ Universidad Espíritu Santo, Km 2.5 Vía, Samborondon, Ecuador \\ Correspondence to: Franklin Isaac Ormaza-González (formaza@espol.edu.ec)
}

Received: 11 January 2016 - Revised: 30 July 2016 - Accepted: 7 August 2016 - Published: 29 August 2016

\begin{abstract}
Skipjack (Katsuwunus pelamis), yellow fin (Thunnus albacares) and albacore (Thunnus alulunga) tunas landed in the Eastern Pacific Ocean (EPO) countries and Ecuador were correlated to the Indexes Oceanic El Niño (ONI) and Multivariate Enso Index (MEI). The temporal series 19832012, and 1977-1999 (warm Pacific Decadal Oscillation, PDO), and 2000-2012 (cold PDO) were analyzed. Linear correlation showed that at least $11 \%$ of the total landings were associated with the MEI, with a slightly negative gradient from cold to warm conditions. When non-linear regression ( $n=6$ ), the $R^{2}$ was higher up to 0.304 (MEI, $r=0.551$ ). The correlation shows high spread from -0.5 to +0.5 for both MEI/ONI; the highest landings occurred at $0.34-0.45$; both indexes suggested that at extreme values $<-1.0$ and $>1.1$ total landings tend to decrease. Landings were associated up to $21.9 \%$ (MEI) in 2000-2012, 1983-1999 rendered lower $R^{2}$ (<0.09); i.e., during cold PDO periods there was a higher association between landings and oceanographic conditions. For the non-linear regression $(n=6)$ a $R^{2}$ of 0.374 (MEI) and 0.408 (ONI) were registered, for the 2000-2012, a higher $R^{2}$ was observed in 1983-1999, 0.443 and 0.711 for MEI and ONI respectively, suggesting that is better to analyze split series (1983-1999, 2000-2012) than as a whole (1983-2012), due to noise produced by the transition from hot to cold PDOs. The highest landings were in the range -0.2 to 0.5 for MEI/ONI. The linear regression of skipjack landings in Ecuador gave an $R^{2}$ of 0.140 (MEI) and 0.066 (ONI) and the non-linear were 0.440 and 0.183 respectively. Total landings in the EPO associated to oceanographic events of high and low frequencies could be used somehow as predictors of the high El Niño o La Niña. There is a clear evidence that tuna fish biomass are at higher levels when the PDO is on cold phase (2000-2030) and vice versa on warm
\end{abstract}

phase (1980-1999). The analysis of the skipjack catch per unit effort (CPUE) on floating aggregating devices (FADs) suggests higher CPUE on FADs (around $20 \mathrm{mt} \mathrm{set}^{-1}$ ) when oceanographic indexes ONI/MEI are below -0.5 . Findings of this work suggest that fishing and management of commercial fish must be analyzed under the light of oceanographic conditions.

\section{Introduction}

In the Pacific Ocean two high frequency events occur on an inter-annual basis; i.e., El Niño and La Nina (e.g. Trenberth and Hoar, 1996), with big/super events occurring around every 15 years (Douglass et al., 2001). Also a lower frequency of 25-30 years, known as the Pacific Decadal Oscillation (PDO), has been detected (Mantua et al., 1997; Mantua and Hare, 2002). There is a huge amount of literature (e.g. Wirtky, 1965; McPhaden 1993, 1999; Trenberth, 1997; Clarke, 2008; Khider et al., 2011, etc.), vast number of web pages (see e.g. NOAA), many long period projects (e.g. TAO-TRITON), more than 20 statistical and dynamics prediction models (ENSO-NOAA) and dozens of institutions and laboratories with hundreds of scientists working on these topics. The effects of El Niño are well known especially because they can bring huge socio-economic losses, epidemics (dengue, malaria, cholera and so on), deaths etc. especially after the two big events 1982-1983 and 1997-1998 (Glantz, 1998). The El Niño event has been and is being deeply researched not only along the Equatorial Pacific Ocean but around the world together with the opposite event, so called La Niña. These events also have relevant impacts on many types of fisheries from demersal to pelagic (small and large 


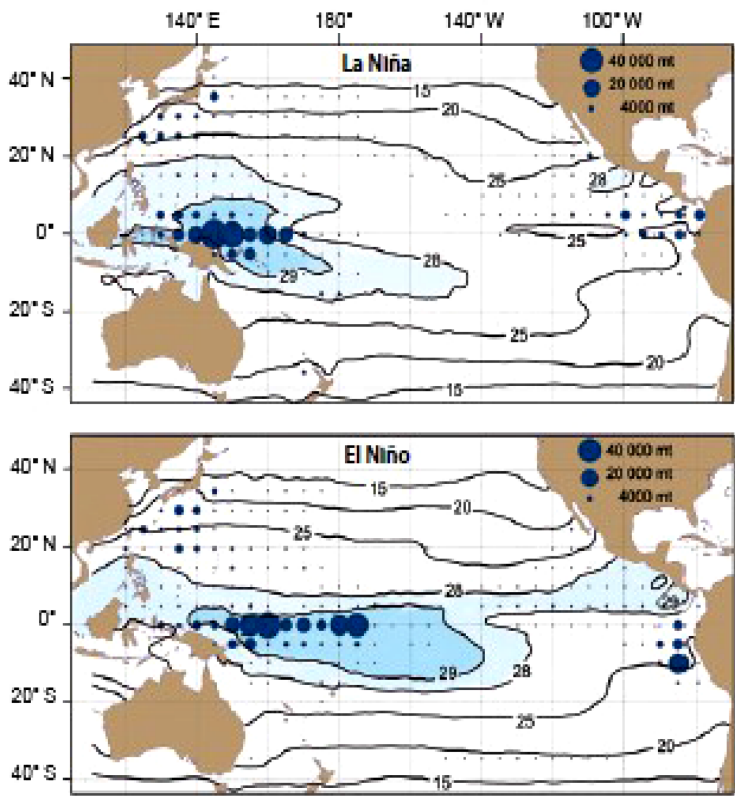

Figure 1. Skipjack tuna (metric tons) catches under la Niña and El Niño events. Sea surface temperatures in centigrade $\left({ }^{\circ} \mathrm{C}\right)$. After WWF (2013). Catch load in metric tons (blue circles).

species). The El Niño event increases sea water column and surface temperatures (leading to thermal anomalies as high as $6{ }^{\circ} \mathrm{C}$; surface temperature $>27^{\circ} \mathrm{C}$, e.g. Trenberth, 1997), lowers salinity, from 35 down to 32 (D'Croz et al., 1991), leads to much lower nutrients and primary production productivity (Chavez et al., 2003), which in turn affects higher trophic levels, bringing positive and negative impacts on fisheries around Ecuador and Peru (Ormaza-González, 2008, 2009a, b, 2010a, b, 2011, 2012a, b; Kimura et al., 2001; Chávez et al., 2003; Ballón et al., 2008; Ormaza-González et al., 2016). Regarding the Pacific Interdecadal Oscillation (PDO), which was initially reported and named by Mantua et al. (1997) in a paper about Alaskan Salmon (Oncorhynchus $\mathrm{sp)}$; this oscillation has been overlooked but a more recent summarizing paper gives good insights into the PDO (Mantua and Hare, 2002) and how this low frequency variation affects long term distribution trends of fisheries. Tuna stocks are affected by these events in diverse manners: distribution, reproduction, recruitment and growth rate (e.g. Lehodey et al., 1997, 1998, 2003, 2006; Lehodey, 2004). Figure 1 shows how the capture is affected by El Niño and La Niña in the western Pacific; most of the catches of skipjack are within the $29^{\circ} \mathrm{C}$ isotherm and as this isotherm widens or narrows in space; the catches follow this change. Thus, during La Niña catches are concentrated around $140^{\circ} \mathrm{E}$, whilst in El Niño are spread from 140 to $180^{\circ} \mathrm{E}$.

Most of the work regarding tuna and the above mentioned oceanographic fluctuations has been made in the western Pacific; tuna distribution and catches in eastern Pacific should be directly impacted by El Niño or La Niña and the PDO; thus the present work tries to find how these oceanographic events have affected tuna catches in the eastern Pacific by statistically correlating them with two oceanographic indexes that are used to determine these low and high frequency events in the Equatorial Pacific.

\section{Materials and Methods}

The El Nino-Enso Indexes: Oceanographic El Niño Index (ONI) and Multivariate Enso Index (MEI) are oceanographic indexes that are accepted as indicators of whether or not El Niño or La Niña is occurring or not. The Oceanographic El Niño (Smith et al., 2008; Null, 2013) index is obtained from sea surface temperature (SST) anomalies computed since 1950 in the so called El Niño 3-4 region whose limits are: $5^{\circ} \mathrm{N}-5^{\circ} \mathrm{S}$ and $120-170^{\circ} \mathrm{W}$, whilst the MEI (Wolter and Timlin, 1993, 1998, 2011) is a multivariable index (SST, zonal and meridional components of surface winds, total cloudiness fraction of the sky, surface air temperature and sea-level pressure) in the same El Niño region; both indexes are available from: http://www.cpc.ncep.noaa.gov/ products/analysis_monitoring/ensostuff/ensoyears.shtml and http://www.esrl.noaa.gov/psd/enso/mei/ respectively. The indexes were averaged on yearly basis from 1983 to 2012 as the available data on tuna landings were total per year. Tuna (total) captured in the eastern Pacific is mainly a composite of skipjack (Katsuwonus pelamis) and yellow fin (Thunnus albacares), that represents $>95 \%$ of all tuna species. Data were obtained from the Inter-American Tuna Tropical Commission, IATTC (Ecuador and Colombia are members of this Regional Fisheries Management Organization) for the Eastern Pacific Ocean: EPO); also catch effort (metric tons per number of sets, $\mathrm{mt} \mathrm{set}^{-1}$ ) on FADs (Floating Aggregating Devices) was also analyzed. The temporal series 1983-2012 was analyzed first, but as this series included both warm and cool PDO, it was split in two series: namely; 1977-1999 (warm), 2000-present (cold).

\section{Results}

Tuna landings, as in any other fisheries, increase as the carrying capacity of the fleet does. Thus, the tuna fleet capacity (purse seiners) has steadily increased since 1961 (32 thousands $\mathrm{m}^{3}$ ) to 2013 (212 thousands $\mathrm{m}^{3}$ ), according to the IATTC (2014). Figure 2 shows landings and MEI/ONI in time (1983-2012) in the EPO (West coast of the Americas to $150^{\circ} \mathrm{W}$, and $40^{\circ} \mathrm{N}-40^{\circ} \mathrm{S}$ ); skipjack and yellow fin tuna captured in this area represented in 2012 around $20 \%$ of the Pacific Ocean and $13 \%$ world catches (around 4.34 million mt; SOFIA, 2014), total landings steadily increased in time as a direct consequence of the fleet capacity from 153788 metric tons (mt) in 1983 to $535385 \mathrm{mt}$ in 2012, with a peak of $742136 \mathrm{mt}$ in 2003. 

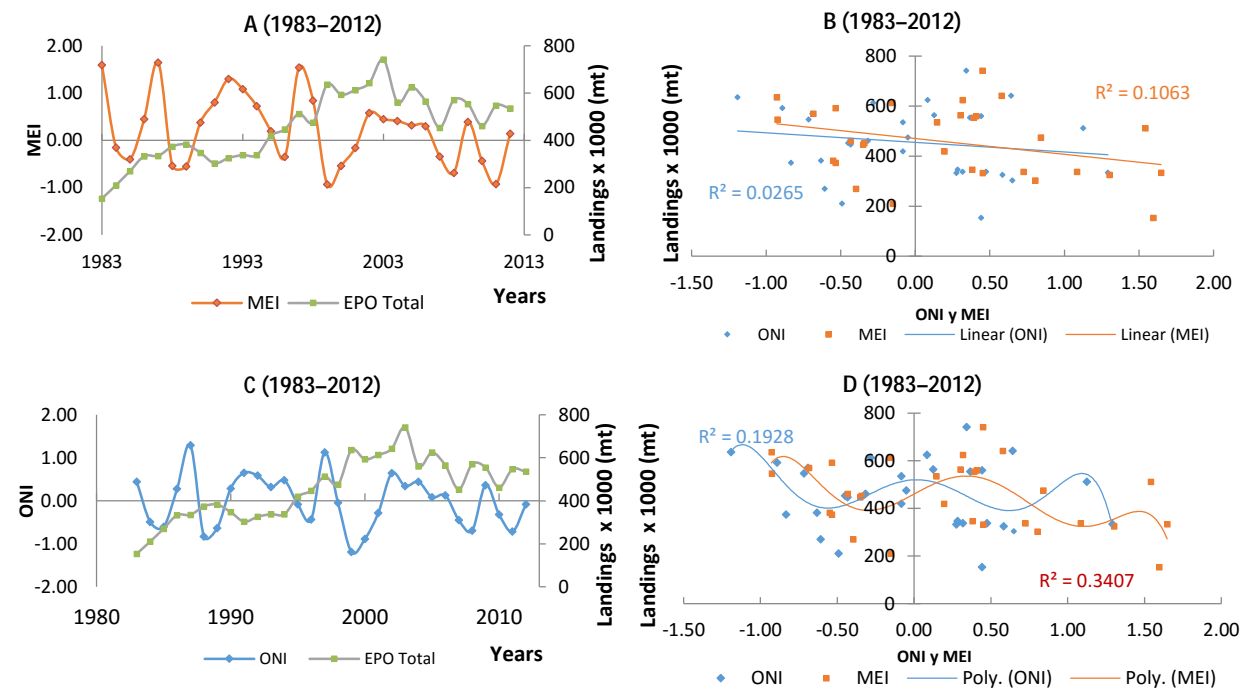

Figure 2. Total tuna landings (mt) in the EPO (1983-2012), MEI (a), and ONI (c) indexes yearly averaged in time, and linear correlation MEI (b) and ONI (d) and landings. Data NOAA and IATTC (2014).

Comparing the behavior of ONI and MEI in time, both presented three peaks of anomalies (above 0.5, Fig. 2) whilst landings were increasing; after 1998 (i.e. during the last warmest event) there is a quick fall. From 2002 a trend of both indexes presents negative gradients that in turn meet the decreasing landings; from these graphs, it is noticeable that up/down peaks/valleys of ONI/MEI indexes to some degree mirror landings. Linear correlation (Fig. 2) shows a $R^{2}$ of 0.026 and 0.106 for ONI and MEI respectively, meaning that at least $11 \%$ of the landings were associated with the MEI index, with a slightly negative gradient, implying that El Niño event tends to lower landings or availability of fish to be caught. When no-linear regression was applied using polynomial function of $n=6$, the $R^{2}$ was higher up to 0.304 (MEI, with a Pearson coefficient of 0.551 ), i.e. $30.4 \%$ of correlation. The correlations showed high spread when MEI/ONI are $>-0.5$ and $<0.5$, the highest landings occurred at indexes of 0.34-0.45; both indexes suggested that at extreme values $<-1.0$ and $>1.1$ landings tend to decrease.

The whole period was divided in two series (Fig. 3) in order to avoid noise of the transition from the warm PDO (1976-1999) to the cool one (2000-present). Landings were linearly associated up to $21.9 \%$ (MEI) in the series 2000present, whilst in the series 1983-1999 rendered lower $R^{2}$ $(<0.09)$. For the non-linear regression, the polynomial function $(n=5)$ obtained a $R^{2}$ of $0.374(\mathrm{MEI})$ and $0.408(\mathrm{ONI})$ for the 2000-2012 series and even higher $R^{2}(n=6)$ were observed in the series $1983-1999$ (0.443 and 0.711 for MEI and ONI respectively), suggesting that during warm periods there was higher association between landings and oceanographic condition on a non-linear basis. Total tuna yearly landings in the EPO data shows that effectively they have decreased $8.1 \%$ (1997-1998) and $14.8 \%$ (2009-2010) dur- ing strong El Niño and La Niña events respectively, however for skipjack tuna these percentages were 12.1 and $36.0 \%$ in the same order. Generally, a year after the warm events, landings increased notably; thus, returning them to average levels similar to the year before events.

In the same way and considering that skipjack tuna makes most of the landings in the EPO the analysis was performed (Fig. 4), finding a lower $R^{2}$ (up to 0.14 or $14 \%$ association) compared against total landings (Fig. 3), but again the highest landings were somewhere in the range from -0.2 to +0.5 for MEI/ONI indexes; also the polynomial functions $(n=6)$ suggest that extreme values El Niño/La Niña) produced a fall in the landings.

Thereafter, similar exercises were run for skipjack landings in Peru, Colombia and Ecuador (Fig. 5), as the coast of these countries are within or close to so-called El Niño region 1-2 (Clarke, 2008); linear correlation provided an association (landings/oceanographic condition) in the range of $7-15 \%$ for the whole series (1983-2012). For the split series 1983-1999 and 2000-2012 (Fig. 5), the $R^{2}$ for the non-linear regressions were as high as 0.940 (Pearson $r=0.969$ ) and 0.695 in that order; i.e., the association up to $94 \%$, whilst the linear correlation gave $7.8 \%$ and $11.1 \%$ with ONI and MEI respectively in the period 1983-1999; and 1.3 and $2.0 \%$ for 1999-2012 in the same order.

Landings of skipjack (1983-2012) only in Ecuador correlated with the MEI/ONI (Fig. 6) and gave a linear regression $R^{2}$ of 0.14 (MEI) and 0.066 (ONI) whilst the non-linear regressions $(n=6)$ were 0.440 and 0.183 respectively. In Ecuador, the impact of the warm/cold high frequency events appear to be higher, thus in 1998 (El Niño) the increase was about $22.7 \%$, whilst during La Niña (2010) the diminution was $38 \%$. 

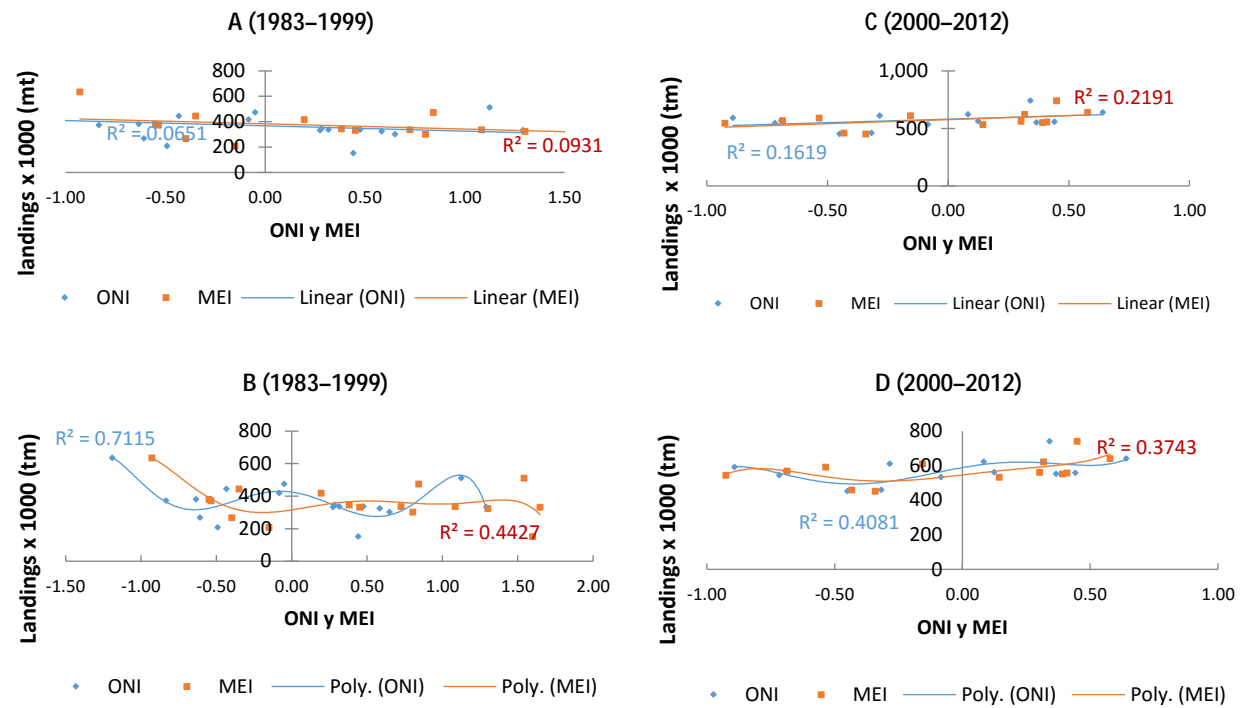

Figure 3. Total tuna landings in the EPO. Linear $(\mathbf{a}, \mathbf{c})$ and non-linear correlation $(\mathbf{b} ; n=6$ and $\mathbf{d}, n=5)$ MEI/ONI for time series $1983-1999$ and 2000-2012. Data NOAA, CIAT (2013).

(a) 1983-2012

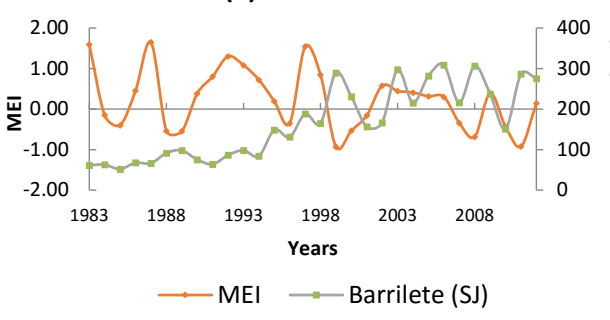

(b) 1983-2012

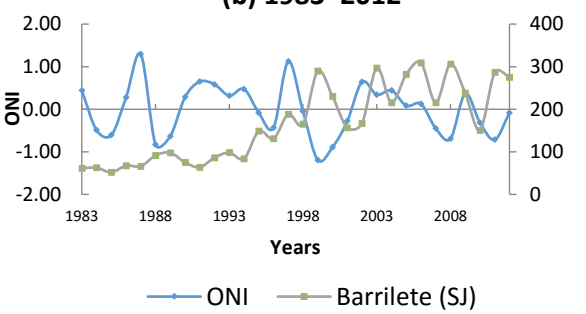

(c) 1983-2012

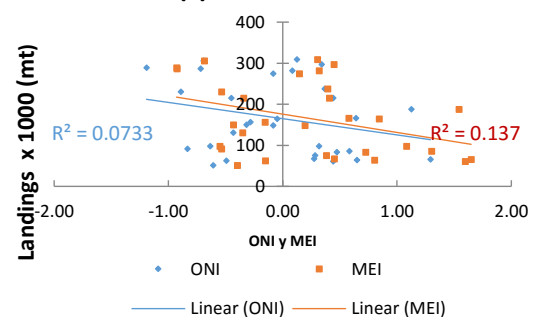

(d) 1983-2012

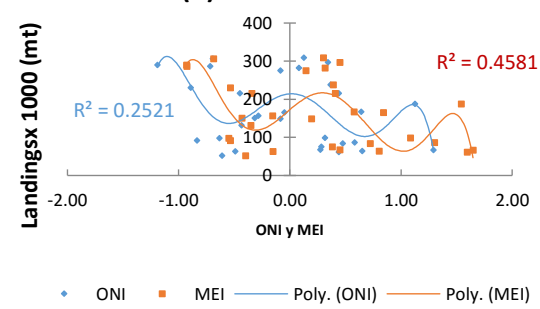

Figure 4. Total Skipjack landings the EPO and MEI (a) and ONI (b) indexes versus time. Linear (c) and non-linear $(n=6$, d) correlation against MEI/ONI for time series 1983-2012. Data NOAA, CIAT (2014).

The skipjack fishing effort ( $\mathrm{mt} \mathrm{set}^{-1}$ on FADs) in the EPO against MEI/ONI was also analyzed (Fig. 7) between 1997 and 2012, the $R^{2}$ s were 0.197 (MEI) and 0.656 (ONI) on a non-linear regression $(n=3)$, the highest fishing effort was at low MEI/ONI values $(<-1.0)$ : over $35 \mathrm{mt} \mathrm{set}^{-1}$. These values suggest that about $20 \mathrm{mtset}^{-1}$ is the average with MEI/ONI in the range of -0.5 to 0.5 , i.e. neutral conditions. For the linear regression again the $R^{2}$ registered that 9.4 and $15.5 \%$ of the effort is associated to the MEI and ONI indexes respectively. Additionally, the polynomial regression suggested that catch effort/set tend to increase at lower than
$-1.0 \mathrm{ONI}$ index, and the contrary for ONI and MEI higher than 1.0.

\section{Discussion}

The above analysis shows that tuna total landings in the EPO are at least $7-14 \%$ linearly associated to oceanographic fluctuations characterized by the MEI and ONI indexes, which are used as predictors of the high frequency fluctuations events El Niño o La Niña. On a longer timescale the Pa- 
(a) 1983-1999

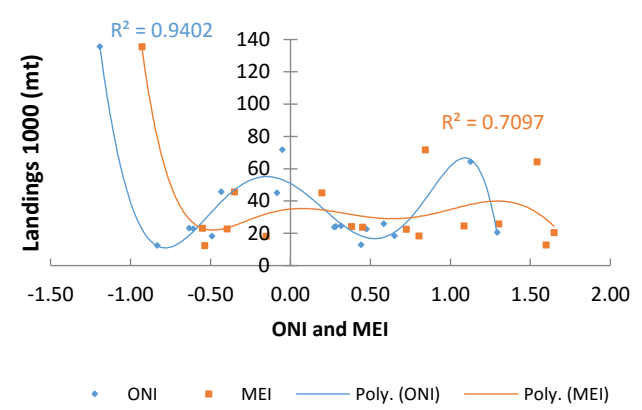

(b) 2000-2012

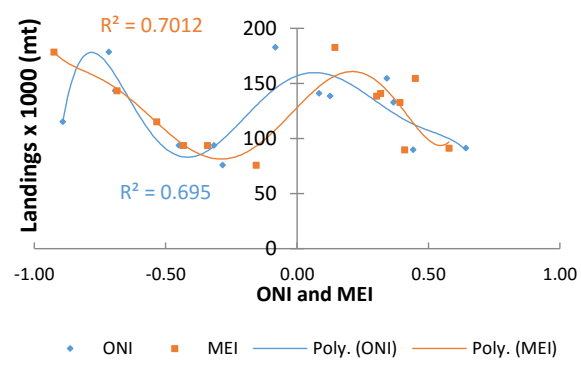

Figure 5. Skipjack landings in Ecuador, Peru and Colombia vs. ONI and MEI. Polynomial functions, $n=6$. Series $1983-1999$ (a) and 2000-2012 (b). Data NOAA, IATTC (2014).

(a) 1983-2012

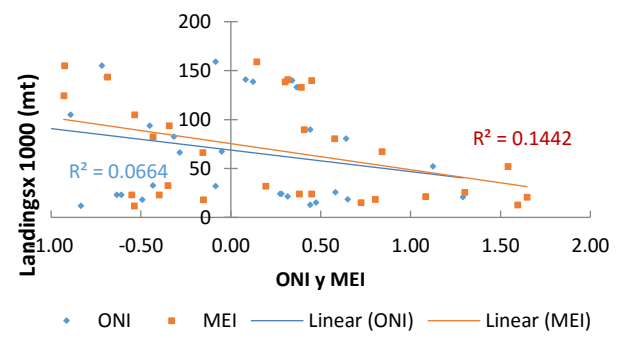

(b) 1983-2012

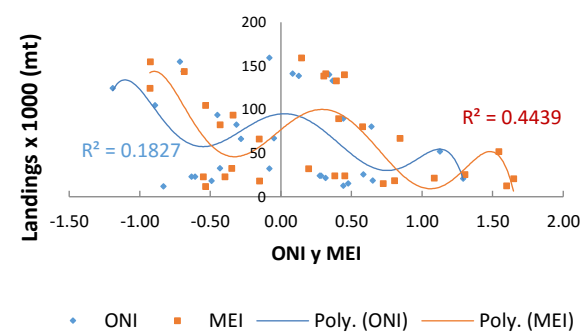

Figure 6. Skipjack landings in Ecuador vs ONI and MEI. Series 1983-2012. Linear (a) and Polynomial Regression (b) $n=6$. Data NOAA and IATTC (2104).

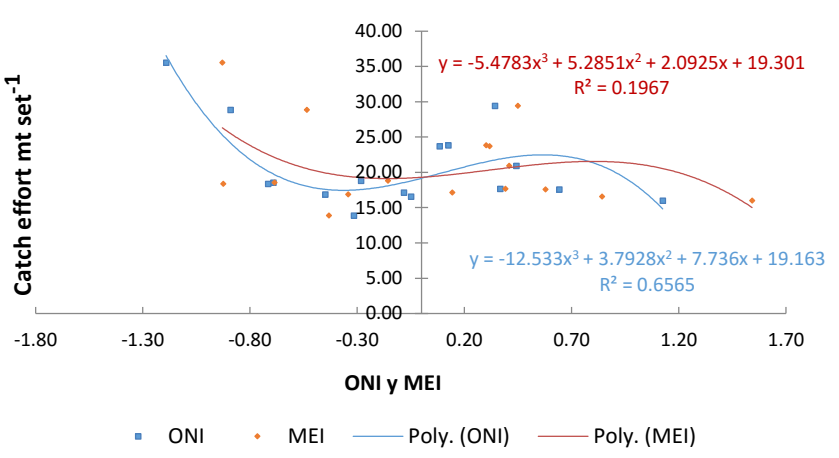

Figure 7. Skipjack fishing effort on FADs and ONI/MEI correlation $(n=3)$ for the series 1997-2012. Red (MEI) and blue (ONI). Data NOAA and IATTC (2014).

cific Interdecadal Oscillation also plays a role, which is reflected in the negative gradient of the equation obtained, suggesting that during cold periods (e.g., 2000-2025/2030) there should be more tuna biomass in the water column, whilst in warm period there should be less. This makes sense as during a cold period upwelling processes prevail thus providing inorganic nutrients to increase photosynthesis at the surface, consequently increasing phytoplankton biomass which is the base of the trophic chain and therefore species at higher trophic will have more energy available. On the contrary, dur- ing El Niño or warm PDO (1979-1999) nutrient poor warm water masses prevail, and hence the base of the trophic chain has less energy to be spread to upper levels. Additionally, tuna as any pelagic species will have to redistribute themselves to find colder and biologically richer water masses because warm waters are relatively low in dissolved Oxygen, as (1) Oxygen is less soluble at higher temperatures and will tend to diffuse back to the atmosphere (like $\mathrm{CO}_{2}$ and many other dissolved gases); and (2) the lack of, or weak, photosynthesis process that transforms $\mathrm{CO}_{2}$ into $\mathrm{O}_{2}$; Lehodey et al. (2010) reported natural mortality increased as habitat parameters like temperature increases and dissolved Oxygen decreases. With less dissolved Oxygen available tuna would need to spend more energy to swim at higher speed just to keep breathing (see, Fitzgibbon et al., 2007).

Under neutral conditions (MEI/ONI > -0.5 and <0.5) there is an important dispersion of fish landings, however the highest landings occurred when the indexes are positive but below 0.5 ; i.e. Neutral condition, according to the accepted definition (see NOAA, 2016). At extreme values of MEI/ONI $(<-1.0$ and $>1.0)$, the non-linear $(n=3$ to $n=6)$ analysis suggests that tuna landings tend to decrease because the habitat values become unsuitable for pelagic fish provoking their redistribution (Lehodey et al., 2010). The statistical analysis gave $R^{2}$ values between 0.4 and 0.8 showings the high association of landings and oceanographic events. 
Regarding fishing effort on FADs, it was found that the catch per unit effort (CPUE) has a linear correlation of 7$14 \%$ with oceanographic conditions, which mirrors landings. A CPUE of about $20 \mathrm{mt} \mathrm{set}^{-1}$ seems to be a representative average when MEI/ONI are between -0.5 and 0.5 , whilst at a positive extreme $(>0.5)$, the polynomial regression indicated that CPUE decreases, and the contrary occurs at extreme negative $(<-0.5)$ values of the indexes. This finding could be an important insight for fishermen and fish managers, who could make their fishing and managing plans more accordingly to oceanographic conditions.

\section{Conclusions}

Even though landings seems not be the best parameter to be correlated to ONI and MEI indexes oceanographic conditions, it was found that there is a consistent $7-10 \%$ of direct influence. In terms of a larger time scale index, such as the PDO, there is uncountable evidence that tuna fish biomass is at higher levels when the PDO is on cold phase (2000-2030). Ormaza-González et al. (2016) have found the length and weight of Opisthonema spp (a type of sardine fish called "pinchagua") have a higher linear correlation up to $40 \%$ to MEI and ONI indexes when data for the fourth quarter of the year was analyzed in time series 2000-2012 of these indexes. Similar outcomes where found when using small pelagic fish correlated to cold phase PDO (OrmazaGonzález et al., 2016). The analysis of the CPUE suggests that fishermen and managers would expect higher CPUE on FADs around $20 \mathrm{mt} \mathrm{set}^{-1}$ when indexes are below -0.5 . These results show that fishing and management of commercial fish must be analyzed under the light of oceanographic conditions, especially those dramatic episodes occurring over short time scales, e.g. during La Niña 2010, when Skip Jack landings dropped by around $36 \%$. Even slight variations in the oceanographic conditions may affect dramatically the biomass of tuna, whose management (like with many other species) is performed using the criterion of the Maximum Sustainable Yield (MSY, e.g. Maunder and Deriso, 2013), especially when managers are working with only half of the carrying capacity of the population $(K / 2)$; the carrying capacity will be undoubtedly influenced by the studied indexes.

Future research for better correlation work could include using length, weight, diet content (to determine medium trophic level), and working with data per quarter or month would render perhaps better and higher correlation coefficients, and much clearer information that would help fishermen and managers to improve their fishing plans and assessment tools respectively. However, the present analysis provides a first effort to predict the impact of oceanographic conditions on fishing and vice versa over short and large time scale.

\section{Data availability}

The data used were obtained through web sites: Oceanographic El Niño Index (ONI) data are available at: http: //www.cpc.ncep.noaa.gov/products/analysis_monitoring/ ensostuff/ensoyears.shtml (see Smith et al., 2008; Null, 2013). Multivariate ENSO Index (MEI) data are available at: http://www.esrl.noaa.gov/psd/enso/mei.ext/table.ext.html (for details see Wolter and Timlin, 2011). Tuna Landings in the EPO: IATTC (http://www.iattc.org/PDFFiles2/ FisheryStatusReports/FisheryStatusReport12.pdf (see IATTC, 2014).

Author contributions. F. I. Ormaza-González: Led and was in charge the whole project. Searched funds. Conceptualized the hypothesis, researched literature, designed material/methods, and wrote the paper in all its stages.

A. Mora-Cervetto and R. Bermúdez-Martínez: Downloaded data on oceanographic indexes and tuna landings, organized data, information and literature research, researched statistical methods, reviewed drafts.

Acknowledgements. This paper is part of the Project SENACYTINAMHI-INP: "EXPLOTACIÓN Y PLANEAMIENTO DE METODOLOGÍA PARA EL DESARROLLO DEL ÍNDICE PESQUERO-PROYECTO ENOS DEL INAMHI" (CDCINAMHI-130-2013). UEES University allowed research time to FIOG to write part of the paper. ESPOL provided time to FIOG to finish and publish the paper. Carlos Naranjo, Raul Mejia and Maritza Aguirre who provided all assistance to fulfill with all project requirements. José Luis Santos (ESPOL), Leader of the Project. Special thanks to all the group of scientists and technicians (INP, INAMHI) that supplied help immediately when requested. P. J. Statham, University of Southampton-UK, generously delivered valuable comments. Daphne Vera Mosquera helped with language corrections.

Edited by: J. D. Pabón-Caicedo

Reviewed by: J. M. Díaz Merlano and L. Moreno

\section{References}

Ballón, M., Wosnitza-Mendo, C., Guevara-Carrasco, R., and Bertrand, A.: The impact of overfishing and El Niño on the condition factor and reproductive success of Peruvian hake, Merluccius gayi peruanus, Prog. Oceanogr., 79, 300-307, 2008.

Chavez, F. P., Ryan, J., Lluch-Cota, S. E., and ñiquen, M.: From Anchovies to Sardines and Back: Multidecadal Change in the Pacific Ocean, Science, 299, 217-221, doi:10.1126/science.1075880, 2003.

Clarke, A. J.: An introduction to the dynamics of El Nino y the Southern Oscillation, Academy press, 301 pp., 2008.

D’Croz, L., Del Rosario, J. B., and Gómez, J. A.: Upwelling and phytoplankton in the Bay of Panama, Rev. Biol. Trop., 39, 233241, 1991. 
Douglass, D. H., Abrams, D. R., Baranson, D. M., and Clader, B. D.: On the Nature of the El Niño/La Niña Events, available at: http://arxiv.org/ftp/physics/papers/0203/0203016.pdf (last access: 23 August 2016), 2001.

Fitzgibbon, Q. P., Strawbridge, A., and Seymour, R. S.: Metabolic scope, swimming performance and the effects of hypoxia in the mulloway, Argyrosomus japonicus (Pisces: Sciaenidae), Aquaculture, 270, 358-368, 2007.

Glantz, M. H.: Currents of Change: Impacts of El Niño and La Niña on Climate and Society, Cambridge University Press, 2nd Edition, ISBN-13: $9780521786720,2001$.

IATTC: Fishery Status Report - Informe de la Situación de la Pesquería, No. 12, published by the IATTC, 190 pp., available at: http://www.iattc.org/PDFFiles2/FisheryStatusReports/ FisheryStatusReport12.pdf, last access: September 2014.

Khider, D., Stott, L. D., Emile-Geay, J., Thunell, R., and Hammond D. E.: Assessing El Niño Southern Oscillation variability during the past millennium, Paleoceanography, 26, PA3222, doi:10.1029/2011PA002139, 2011.

Kimura, S., Inoue, T., and Sugimoto, T.: Fluctuation in the distribution of low-salinity water in the North Equatorial Current and its effect on the larval transport of the Japanese eel., Fish. Oceanogr., 10, 51-60, doi:10.1046/j.1365-2419.2001.00159.x, 2001.

Lehodey, P.: Climate and fisheries: an insight from the central Pacific Ocean, in: Marine Ecosystems and Climate Variation: the North Atlantic, edited by: Stemseth, N. Chr. and Ottersen, G., Oxford University Press, Oxford, ISBN-10: 0-19-850748-8, 138-146, 2004.

Lehodey, P., Bertignac, M., Hampton, J., Lewis, A., and Picaut, J.: El Niño southern oscillation and tuna in the western Pacific, Nature, 389, 715-718, 1997.

Lehodey, P., Andre, J. M., and Bertignac, M.: Predicting skipjack tuna forage distributions in the equatorial Pacific using a coupled dynamical bio-geochemical model, Fish. Oceanogr., 7, 317-325, 1998.

Lehodey, P., Chai, F., and Hampton, J.: Modelling climaterelated variability of tuna populations from a coupled ocean-biogeochemical-populations dynamics model, Fish. Oceanogr., 12, 483-494, 2003.

Lehodey, P., Alheit, J. , Barange, M., Baumgartner, T., Beaugrand, G., Fromentin, J. M., Hare, S. R., Ottersen, G., Perry, R. I., Roy, C., van der Lingen, D., and Werner, F.: Climate variability, fish and fisheries, J. Climate, 19, 5009-5030, 2006.

Lehodey, P., Senina, I., Sibert, J., Bopp, L., Calmettes, B., Hampton, J., and Murtugudde, R.: Preliminary forecasts of Pacific bigeye tuna population trends under the A2 IPCC scenario, Prog. Oceanogr., 86, 302-315, 2010.

Mantua N. J. and Hare, S. R.: The Pacific decadal oscillation, J. Oceanogr., 58, 35-44, doi:10.1023/A:1015820616384, 2002.

Mantua, N. J., Hare, S. R., Zhang, Y., Wallace, J. M., and Francis, R. C.: A Pacific interdecadal climate oscillation with impacts on salmon production, B. Am. Meteorol. Soc., 78, 1069-1079, 1997.

Maunder, M. N. and Deriso, R. B.: A stock-recruitment model for highly fecund species based on temporal and spatial extent of spawning, Fish. Res., 146, 96-101, 2013.

McPhaden, M. J.: TOGA-TAO and the 1991-93 El Niño-Southern Oscillatino Event, Oceanography, 6, 36-44, 1993.
McPhaden, M. J.: Genesis and Evolution of the 1997-98 El Niño, Science, 283, 950-954, doi:10.1126/science.283.5404.950, 1999.

NOAA: Equatorial Pacific Sea Surface Temperatures, available at: https://www.ncdc.noaa.gov/teleconnections/enso/indicators/ sst.php, last access: 20 August 2016.

Null, J.: El Niño and La Niña Years and Intensities Based on Oceanic Niño Index (ONI), Golden Gate Weather Services, available at: http://ggweather.com/enso/oni.htm (last access: $20 \mathrm{Au}-$ gust 2016), 2013.

Ormaza-González, F. I.: Eventos oceanográficos y pesquerías del atún, Ecuador Pesquero, Vol. 44, Año 12. pp., 14. Pub. por Cámara de Pesquería del Ecuador, 2008.

Ormaza-González, F. I.: La Niña 2008-2009: El periodo interdecadal frío y las pesquerías del dorado, Ecuador Pesquero, Vol. 47, Año 14. pp., 34. Pub. por Cámara de Pesquería del Ecuador, 2009a.

Ormaza-González, F. I.: La oceanografía en el Pacífico CentralEste durante 2009 y sus pesquerías pelágicas, Ecuador Pesquero, Vol. 51, Año 14. pp., 42-43. Pub. por Cámara de Pesquería del Ecuador, 2009b.

Ormaza-González, F. I.: Fenómeno La Niña, Su posible impacto en las pesquerías. Ecuador Pesquero, Vol. 55, Año 15. pp., 2629. Pub. por Cámara de Pesquería del Ecuador, 2010a.

Ormaza-González, F. I.: Fenómeno La Niña del 2010 se extiende al 2011 y 2012, Su impacto en los recursos pesqueros, Ecuador Pesquero, Vol. 59, Año 15 pp., 38-39. Pub. por Cámara de Pesquería del Ecuador, 2010b.

Ormaza-González, F. I.: Post La Niña del 2010: Condiciones oceanográficas e impacto pesquero, Ecuador Pesquero, Vol. 57, Año 15. pp., 24-25. Pub. por Cámara de Pesquería del Ecuador, 2011.

Ormaza-González, F. I.: Posibles impactos del invierno en pesquerías, Condiciones oceanográficas en el 2012, Ecuador Pesquero Vol. 61, Año 15 pp., 18-19. Pub. por Cámara de Pesquería del Ecuador, 2012a.

Ormaza-González, F. I.: Un Niño en el Pacífico Central en un período interdecadal frío? Ecuador Pesquero, Vol. 63, Año 16 pp., 18-20. Pub. por Cámara de Pesquería del Ecuador, 2012b.

Ormaza-Gonzàlez, F. I., Mora-Cervetto, A., Bermúdez-Martínez, R. M., Hurtado-Domínguez, M. A., Peralta-Bravo, M. R., and Jurado-Maldonado, V. M.: Can small pelagic fish landings be used as predictors of high-frequency oceanographic fluctuations in the 1-2 El Niño region?, Adv. Geosci., 42, 61-72, doi:10.5194/adgeo-42-61-2016, 2016.

Smith, T. M., Reynolds, R. W., Peterson, T. C., and Lawrimore, J.: Improvements NOAAs Historical Merged LandOcean Temp Analysis (1880-2006), J. Climate, 21, 22832296, doi:10.1175/2007JCLI2100.1, 2008 (data available at: http://www.cpc.ncep.noaa.gov/products/analysis_monitoring/ ensostuff/ensoyears.shtml).

SOFIA: The state of world fisheries and aquaculture 2012, Food and Agriculture Organization of United Nations, Rome, 2014 FAO Fisheries and Aquaculture Department, 243 pp., 2014.

Trenberth, K. E.: The definition of El Niño, B. Am. Meteorol. Soc., 78, 2771-2777, doi:10.1175/15200477(1997)078<2771:TDOENO>2.0.CO;2, 1997. 
Trenberth, K. E. and Hoar, T. J.: The 1990-1995 El Niño-Southern Oscillation Event: Longest on Record, Geophys. Res. Lett., 23, 57-60, 1996.

Wirtky, K.: Corrientes superficiales del Océano Pacífico Tropical, Boletín de la Comisión, Interamericana del Atún Tropical, 9, 279-304, 1965.

Wolter, K. and Timlin, M. S.: Monitoring ENSO in COADS with a seasonally adjusted principal component index, Proc. of the 17th Climate Diagnostics Workshop, Norman, OK, NOAA/NMC/CAC, NSSL, Oklahoma Clim. Survey, CIMMS and the School of Meteor., Univ. of Oklahoma, available at: http://www.esrl.noaa.gov/psd/enso/mei/WT1.pdf, 52-57, 1993.
Wolter, K. and Timlin, M. S.: Measuring the strength of ENSO events - how does 1997/98 rank?, Weather, 53, 315-324, 1998.

Wolter, K. and Timlin, M. S.: El Niño/Southern Oscillation behavior since 1871 as diagnosed in an extended multivariate ENSO index 110 (MEI.ext), Int. J. Climatol., 31, 1074-1087, doi:10.1002/joc.2336, 2011 (data available at: http://www.esrl. noaa.gov/psd/enso/mei.ext/table.ext.html).

WWF: WWF-South Pacific, Impacts of Climate on Tuna Fisheries, Fact Sheet, available at: http://awsassets.panda.org/downloads/ climate_change_factsheet_final_1.pdf, 2013. 